\title{
Reading First, Science Last: An Investigation into Reading Comprehension Strategy Usage in Science Education
}

\author{
Carol Fetters, Ph.D. (Corresponding Author) \\ School of Education, University of St. Thomas \\ Houston, Texas 77006 \\ Tel: 1-713-525-3863Ｅ-mail: fetter@stthom.edu \\ Evan Ortlieb, Ph.D. \\ Faculty of Education, Monash University \\ Frankston, Victoria 3199 Australia \\ Tel: +61 0399044661 E-mail: evan.ortlieb@monash.edu \\ Earl H. Cheek, Jr., Ph.D. \\ School of Education, Louisiana State University \\ Baton Rouge, LA 70803 \\ Tel: 1-225-578-6867_Email: echeek@1su.edu
}

Doi:10.5296/jsr.v5i1.5528 URL: http://dx.doi.org/10.5296/jsr.v5i1.5528

\begin{abstract}
This qualitative exploration was designed to examine strategy-based reading instruction using science expository text in grades 2-5. This study centered on case studies of six elementary teachers and how they used reading strategies during science instruction. Findings revealed that although the teachers' use of expository text was limited, teachers utilized particular reading strategies that extended and elaborated the students' oral discussions during science instruction. The classroom conversations about science topics extended the students' background knowledge of the science concepts that related to science expository text materials in grades 2-5. Further research could include alignment of reading strategy instruction with science instruction using print materials that are matched with the students' instructional reading levels.
\end{abstract}

Keywords: Expository Text; Reading; Elementary Teacher; Comprehension; Strategies

\section{Introduction}

Reading strategies related to comprehending expository text in the elementary grades 
continue to be a hotly debated topic, especially in the content area of science. The National Center for Education Statistics in (2006) reported no significant change in the percentage of fourth graders at or above grade level in the United States between 1992 and 2005. Since societal success is dependent on students' ability to learn, we must advance students' abilities to comprehend text. In 1996, The International Reading Association (IRA) and the National Council for Teachers of English (NCTE) jointly published the Standards for the English Language Arts that succinctly outlines 12 literacy guidelines that have become the definitive national description of good teaching and learning of literacy. Yet, Lee, Grigg and Donahue (2007) as well as Snow (2002) contend that our students continue their plight when compared to other countries on measures including reading comprehension. Furthermore, Walpole, Justice, and Invernizzi (2003) and Pressley (2002a) concluded that teachers rarely provide explicit instruction on strategies that emphasize reading comprehension.

Language is both a means of doing science as well as the communication through which we construct scientific claims (Yore, 2004). Literacy is important to science education because it aides in the process of reading, analyzing, and evaluating scientific information. Scientists' use language and writing within their discourse communities (Saul, 2004). Yore's work provided a clear vision of science literacy, which is the central focus of the United States National Science Education Standards (National Research Council [NRC], 1996). Also, the National Science Education Standards (NCES) adopted in 1996 include a standard that states that "the program of study in science should connect to the other school subjects" ([NRC] 1996). Since reading comprehension is necessary to understand science texts, these two subjects have a fundamental connection.

Pressure for improved standardized-test performance and state standards related to informational text has created an intense focus for teachers to recognize that students must be better prepared to understand expository text. The No Child Left Behind Act (2001) has led towards increased pressure on teachers to raise math and reading scores, so often times other content areas, including science, have been skimmed over or completely ignored. However, with recent mandated testing in science, teachers will have to spend more time on science instruction.

The purpose of this study was to explore strategy-based reading instruction within science class in second, third, fourth, and fifth grade. The researcher's focus was centered on exploring these central queries for this case study:

1. What reading strategies do elementary teachers use with their students to ensure effective reading comprehension of expository science text materials?

2. How, if any, are there similarities and differences in the use of reading strategies with expository science text between second, third, fourth and fifth grade?

\section{Conceptual Framework}

\section{Reasons for Using Expository Text Literacy}

Perhaps the most widely cited recommendation for increasing reading comprehension is 
increasing explicit instruction in reading comprehension strategies (NRP, 2000). Incorporating informational books and other forms of expository science text into classrooms in the early grades has a number of benefits. Children enjoy informational books more than the traditional narrative stories that populate most classroom libraries and reading curricula. Secondly, informational text encourages the home-school connection, as they more closely resemble the topics that parents discuss and read about with their children at home (Duke, 2006). In addition, there are often more substantive, meaning-making conversations between teachers and children when they read aloud from information texts rather than narratives (Smolkin \& Donovan, 2003). Those conversations are vital to building children's understanding of how to read to learn while they are learning to read (Cramer, Ortlieb, \& Cheek, 2007, 2008; Ortlieb, Cramer, \& Cheek, 2007).

Comprehension skills differ from other major components of reading. Decoding skills can be mastered though highly effective teachers' instruction and most students can automatically use their basic skills to decode new vocabulary words. Comprehension skills require students' continuous development toward more advanced comprehension competencies through the application of self-guided thinking throughout every reading experience (Ortlieb \& Cheek, 2008, 2012, 2013a, 2013b; Ortlieb, Cheek, \& Verlaan, 2013; Ortlieb, Verlaan, \& Cheek, 2013). This guided self-monitoring process is known as "metacognition," or thinking about one's thinking.

Comprehension process lessons are taught in three types: teacher directed lessons that include demonstrations of comprehension processes, one-on-one setting with the teacher providing individualized, teachers using explicit direct instruction, and thirdly, lessons in which students choose which comprehension process they want to learn more about. The third type of lesson produces highly significant gains in children's understanding because young readers become more metacognitively aware and motivated to learn because they are involved in choosing what is important for them to learn next to improve their reading abilities (Block, Rodgers, et al., 2004).

In elementary schools, the emphasis is on teaching reading skills (Ortlieb, 2013). As students progress through the elementary grades, academic demands increase especially in reading expository text materials in science and social studies. Kamil (2000) posited that the ability to comprehend expository text in content-area texts is critical to our students' academic success.

\section{Exposure Leads to Motivated Readers}

Explicitly teaching strategies may still not be enough to develop self-regulated students who independently employ strategies. Some instructional experts and researchers recommend including a motivational component that focuses on meaningfulness, including interest and value (Alexander, 1997; Anderman \& Wolters, 2006; Ortlieb \& Marinak, 2013). Learning and applying strategies takes quite a lot of effort, so students want to see some value in putting forth extra work so they often need to be convinced of how what they are asked to do will 
benefit them. If teachers provide a convincing rationale for each strategy they teach (Paris, Lipson, \& Wixson, 1983), students are more likely to be interested in the strategy instruction. Teaching students how strategies help the brain work more effectively (Gaskins, 2008) helps students enjoy interesting stories and sophisticated information about learning theory and knowledge about how the brain functions (Ortlieb, 2014). In teaching students to access background knowledge, the teacher might say:

We access background knowledge to help us become actively involved by relating what we are reading to what we know. We want to hook new information to what we already know, because it is easier to get information back out of our brain if it is hooked to what we already know. (p. 197)

Teachers explain how learning works by sharing principles of learning with students (Gaskins, 2008). Gaskins' findings can be applied using strategy instruction with expository science text.

\section{Science Learning Methods}

Figure 1 illustrates standards that places emphasis on requisite skills needed for students to attain scientific literacy. The National Science Education Standards (NCES) offered the following definition for both researchers and practitioners: "Scientific literacy is the knowledge and understanding of scientific concepts and processes required for personal decision making, participation in civic and cultural affairs, and economic productivity" (NRC, 1996, p. 22). For purposes of this exploration, we will identify three methods for science learning as inquiry, explicit or direct instruction, and reading diverse texts. Prior to the completion of the NCES Standards (1996), science instruction in classrooms did not necessarily emphasize text structures or enthusiastic student discussions about abstract concepts. The NCES standards emphasized student engagement in science lessons and an even more crucial need for students to be able to locate, evaluate, and comprehend expository text and other informational text.

\section{Explicit Instruction}

As academic demands on our students becomes more complicated, explicit reading instruction decreases (Alexander \& Jetton, 2000). However, the approach to strategies instruction most frequently supported by research, especially for children with learning problems, is the approach that features explicit teacher explanations of the what, why, when, and how of using strategies, accompanied by teacher modeling, scaffolding, and guided practice (Lipson, 2007). Although explicit explanation of strategies is not practiced in most classrooms, two such programs that have received empirical support are Project CRISS (Santa, Havens, \& Valdes, 2004) and Transactional Strategies Instruction (Pressley, El-Dinary, Gaskins, Schuder, Bergman, et al., 1992). These programs provide direct and explicit instruction in the reading, writing, and thinking strategies needed for success in content-area courses in science and social studies. Both programs emphasize professional development. In part, explicit teacher-led approaches are not commonplace in classrooms because they are dependent on excellent pre-service and in-service professional development. The explicit approach has also been found to be difficult for teachers to put into practice (Hilden \& Pressley, 2007). Research in explicit teacher-led instruction indicates that direct teaching of 
strategies allows students to be able to read informational books while allowing them to develop literacy skills (Beckers, Cheek, \& Ortlieb, 2009; Laster, Ortlieb, \& Cheek, 2009; Ortlieb \& Doepker, 2009).

Reading comprehension or making meaning of the printed word is the ultimate goal of reading instruction (Cassidy \& Ortlieb, 2011, 2012, 2013a, 2013b; Cassidy, Ortlieb, \& Shettel, 2010/2011 a, b). However, during the last decades, many reading researchers have focused their attention on work-level skills because of the assumption that word decoding is the bottleneck of the meaning getting process (Pressley, 2002b; Snow, Burns, \& Griffin, 1998). Research on the components that potentially influence comprehension has been on parallel paths for the past several decades, to some extent insulated from one another (Gaffney \& Anderson, 1991). There is a definite need for further research in the area of explicit strategy instruction.

Research regarding reading comprehension in all areas of the curriculum strongly suggests that effective strategies instruction includes explicit explanations, modeling, scaffolding, and practice (Pressley, 2006). Teachers of effective strategies instruction explicitly explain to students (1) what the strategy is that can be used to accomplish a specific task, (2) why and how the strategy facilitates learning, and (3) how and when to use the strategy (Gaskins, 2005). Dimino (2007) found that teachers can encourage students to think aloud to share their thinking while using the strategy in authentic situations.

As part of explicit strategies instruction, teachers guide, support, and cue students as they gradually release responsibility to students for putting a strategy, or a bundle of strategies, to work. The teacher scaffolds (supports) students in the application of strategies during guided practice, much like learning to ride a bicycle, until the student can use the strategy or strategies independently.

\section{Exposure to Diverse Text}

Sometimes students have difficulty in identifying relationships within expository text passages, particularly in the content areas of science and social studies. Collins and Cheek (1999) noted that as students' knowledge of the organization of expository text structure improves, comprehension will improve, as well. There is a great need for students to be aware of the text structures of expository text as they develop as readers beyond the emergent reader stage so that they can be successful lifelong readers. Interaction with expository text requires additional strategies that specifically address the demands of expository text. The strategies can help students cope with demands of the language of expository test, and should be connected by focusing on the functions that expository language serves in the presentation of information, structure of the text, and carried out in a manner that gradually removes the scaffolds in the instruction. As Yore (2004) described in his discussion of strategy instruction with science texts:

The instruction should be embedded in the actual text assigned and should reflect the interactive, constructive aspects of making sense of text and of effective explicit 
instruction....The selected strategy should be modeled by the teacher, practiced by the students with guidance from the teacher, used in controlled situations by students with assigned text, and transferred in other reading assignments and texts by the students. (p. 88)

The strategies approach to teaching reading comprehension strategies centers on the direct teaching of specific procedures, such as summarizing, making inferences, and generating questions, and using them in working with text (McKeown, Beck, \& Blake, 2009). Strategy-based instruction can be viewed from the traditional perspective framework of before, during, and after reading. The strategies approach to teaching reading developed from models of thinking and learning processes, whereas the content approach of teaching reading stems from a model of text processing.

Teachers need to provide a literacy rich environment in their classroom with exposure to a variety of text materials including science textbooks, trade books, informational books on content area topics of instruction, as well as a variety of expository materials that are matched to the instructional levels of the students. Moss (2005) notes:

About half the classroom library should be devoted to engaging informational books and biographies, and this percentage should increase as children move through the grades. Some books should be pertinent to classroom topics of study, while others should have a broader appeal. Students can use these books for vocabulary reading inquiry, study, reference, or browsing. (p. 63)

As elementary students select reading materials that are provided in a literacy rich classroom setting, students are motivated to "mine for gems" of information that are embedded in the array of expository materials. The exposure to diverse reading materials allows students to build background knowledge that connects to their own prior knowledge about science topics related to their individual interests and reading levels.

\section{Methods}

\section{Observations}

Participant observation was selected as the qualitative means of inquiry to investigate strategy-based reading instruction using expository science text in grades 2-5. This research method allowed the primary investigator to study from both an inside and outside the classroom perspective at this urban public elementary school. The primary researcher observed 1 second grade, 2 third grade, 2 fourth grade, and 1fifth grade teacher for 10 weeks for this exploration, including the ongoing activities that occurred in the classroom environment during science instruction and selected activities that were pertinent to this study.

Record keeping was essential to this exploration; a detailed record was maintained of ongoing events from the six participant classroom teachers who were responsible for teaching all subject areas. Both objective observations and personal feelings (Spradley, 1980) were recorded. Furthermore, formal and informal interviews served to provide a wealth of insight 
into classroom proceedings throughout the data collection process. Observation combined with interviewing is a powerful combination that allows the researcher to observe people, and solicits their ideas about what their behavior means (DeWalt \& DeWalt, 2002; Spradley, 1980).

Written field notes were the primary means in which observations were recorded for subsequent analysis. The researcher used a simple system of keeping a field notebook for the course of the study. Spradley (1980, p. 71) suggests that "qualitative researchers utilize field notes to remind them of events "Like a diary...this journal...contain[s] a record of experiences, fears, mistakes, confusions, breakthroughs, and problems that arise during field work," that otherwise might be forgotten. A rating scale for teacher observations, adapted from Ortlieb (2008), and a teacher observation form developed by the researcher provided simultaneous techniques for gathering information from the classroom observations (see Figures 2 and 3). The researcher observed each of the six teachers in order to gain a sense of the teacher's instructional style, demeanor, the classroom setting, and to sense whether the teacher proved suitable for the study. After the initial observations, the researcher conducted subsequent observations to see how science lessons built upon one another. Classroom observations occurred on various days of the week. Since the researcher explored for both similarities and differences among the grade levels, written observations were constructed from the observations and field notes for each of the six teachers.

\section{Teacher Interviews}

In addition to the observations that were conducted in the natural setting of science instruction in the teachers' classrooms, individual and frequent informal interviews were conducted with the campus principal and a key informant, and each of the six teachers who participated in this study. An interview with the school principal took place at the beginning of the exploration. Other informal interviews, such as encounters with the principal in the hallway or outside on the sidewalk were ongoing. An interview with the school principal took place at the beginning of the exploration. Other informal interviews, such as encounters with the principal in the hallway or outside on the sidewalk were ongoing throughout the study. The formal teacher interviews also took place at the onset of the study, and were scheduled in the teachers' classrooms when students were not present in the room. Other informal interviews with the teachers took place as questions arose during the classroom observations. The collection of data for this study remained flexible and ongoing.

A reading specialist who served as the math and science coordinator on the research school site, served as a key informant for this exploration. The key informant was also interviewed at the beginning of the study. During the study, the researcher had frequent informal conversations with the key informant and the six teachers in the hallways, on the playground, or on the sidewalk, and sometimes in informal meetings about information that pertained to the study. The key informant served as a resource for information about the culture of the school site research site.

\section{Findings}

Several notable similarities existed between the six teachers in this study. Teacher participants 
varied in both their socioeconomic and teaching experience backgrounds. Two of the six teachers were African American and four of the teachers who participated in the study were Caucasian. All of the teachers who participated in this study were educated in the same state in which the study was conducted, and their experience ranged from 2 to 14 years of classroom experience.

There were frequent references to reading strategies during the observations of the science instruction during the last 30 minutes of the school day. When the researcher questioned the participant teachers about their use of expository text materials for science instruction, it came as a surprise to the researcher that none of the teachers in this study used printed text materials or a science textbook for explicit print related expository text instruction. The information that the science textbooks were not being used was also verified by the Principal as well as a Key Informant. The science textbooks were located in the teacher's closets or were displayed on a classroom shelf. However, the science textbooks were not used during any of the observations for this study, nor were they ever referred to by any of six teachers in this study. When further questioned by the researcher about why the science textbooks were not used for any of the grade levels, the teachers who participated in this study all answered with the same answer that the science textbooks were too difficult for the students to use. Therefore, the students' exposure to the science text that is correlated to the science curriculum for the state and local guidelines was extremely limited. Although there were extensive conversations and discussions about science concepts and topics, there were minimal connections made to expository printed text other than standardized practice test materials using expository text structures.

In the second grade classrooms, no practice test booklets were used. Instead, there were frequent classroom discussions surrounding the use of the Magic School Bus books which are considered as informational trade books that mix both narrative and expository text. Often during the observations the fourth and fifth grade teachers utilized the student practice booklets to reinforce the reading strategies that were being used with the particular passages of the standardized test practice booklets science text. This was particularly true in the third, fourth, and fifth grade classrooms in which this research study was conducted. Since it was not the researcher's focus, the type of expository that the teacher chose to use was not an issue. However, the teachers indicated in their interviews that they did not allow student choice of expository materials in the classrooms.

Most of the observations were large group discussions. One of the third grade teachers used small group instruction, but the majority of the classroom observations used large group instruction with oral discussions. The classroom discussions had high levels of student engagement, and all six teachers extended the discussions of the students in all grade levels from second through the fifth grade. Field notes from the observations noted that there was $75-100 \%$ student engagement in conversation throughout the science topic discussions.

Although there was a high level of student engagement during the classroom science 
discussions, the students were limited to the availability of science text for the discussions. The second grade and fourth grade teachers had blue plastic book bins with selections of expository text materials for the students to choose reading selections from, but the blue plastic book bins were not labeled with science topics nor were they set up for student engagement in science center activities during the science instruction that was observed by the researcher.

All of the six teachers in this study used questioning strategies in their instruction. Most of the teachers, especially the third grade and the fifth grade teachers in this study, extended and elaborated on the students answers during class discussions.

\section{Similarities and Differences in Instructional Strategies}

In examining and analyzing field notes, the researcher noticed that the teachers used some similar instructional strategies across the grade levels. Throughout the duration of the study, there was a limited variety of text available to the students in the classrooms. Although there was a limited amount of a variety of expository text materials, all six of the teachers encouraged active student participation and student engagement in oral discussions. The classroom discussions in the second, third, fourth, and fifth grade centered on science topics during the science instructional time. All six of the teachers in this study used conversation and discussion. However, when analyzing the classroom observations across the grade levels, the researcher noted that there was a minimal use of expository test materials during science instruction.

Elaboration of student discussion and clarifying concepts through oral discussion was evident throughout the study; however, there was a limited amount of expository text print that connected the conversations with printed text or printed vocabulary words. Oral discussion extended the students' background knowledge about science topics. Since instruction was observed during the last thirty minutes of the day, it was difficult for the researcher to discern whether the strategies that the teachers were using were explicitly taught during the morning reading block. Since the research site is constrained by federal mandates for reading funding, the morning reading instructional block is structured and has very specific curriculum guidelines. With the time constraints for the mandated time for reading instruction, there was a minimum amount of time available during the school day for science instruction. Another consideration for the time constraints is the Response to Intervention (RTI) focus on interventions that occur throughout the school day.

The researcher noted a concern that there was minimal use of informal assessment to monitor student comprehension of the verbal discussions, minimum exposure to connect conversations to expository printed materials or science text structures. This concern can provide opportunities for further research about how to make connections with print resources that extend whole class conversations about expository text topics.

\section{Interviews}

Interviews coupled with classroom observation were analyzed and the emergent themes of 
the interview supported the emergent themes of the classroom observations. Time barriers for explicit science instruction, lack of assessment in science instruction, the use and availability of print resources for expository science text, and oral discussion and conversation as common instructional strategies emerged as themes through interviews with the school Principal, the key informant, and the teachers who participated in the study.

Time barrier. In an interview, the principal noted that time is the biggest barrier to science instruction. Since the research site depended on federal funding programs for reading, and the federal program required specific times during the day for reading and math instruction, there was a minimal amount of available instructional time left to teach science. All teachers in the study agreed that time was the biggest barrier to teaching science. The key informant who participated in this study was a reading specialist who was serving as an instructional math coach on the campus. An interview with the key informant highlighted that time was definitely a barrier to science instruction because so much time was devoted to math and reading interventions during the school day due to the Response to Intervention (RTI) that there is minimal time left in the school day for science instruction.

Assessment. The principal indicated in an interview that she evaluated learning by the students' test scores, and emphasized that test scores are the criteria that she used to judge whether learning was taking place in the classroom. In contrast, the teachers' interviews in this study indicated that the criteria for they used for judging student success was established by the students' ability to orally share information during the conversations that took place during the science instruction. It was interesting for the researcher to distinguish the stark contrast between the principal's and the teachers' perceptions of how to evaluate effective science instruction. A third grade teacher underscored her belief that third graders have wide range of levels of ability and mentioned that she used student observation as an assessment tool for the third grade students; whereas, a fifth grade teacher in an interviewed shared that she frequently assessed individual student learning through the oral discussions and conversations that took place during science instruction related to informational text.

Common strategies. When questioned about the most important reading strategies that students need to possess as successful readers, the Principal accentuated her belief that students need the ability to decode words, restate ideas, and read and understand directions. Interestingly, of the six teachers who were interviewed for this study, three of the six teachers emphasized decoding in reading as foremost in student success, along with the importance of students being able to restate main ideas in reading passages, and be able understand what they hear. However, overarching strategies noted by the researcher during observations were oral discussions and conversations about science that did not utilize print resources, and did not align with the strategies that the participants' interviews cited as foremost in student success: restating main ideas about printed passages or restating what the students hear.

Availability of print resources. Both the key informant as well as four out of six of the teachers in this research study mentioned the absence of science books for science 
instruction in second through fifth grade classrooms. Some teachers utilized science materials that they had collected in their classroom to enhance the science curriculum, but indicated that availability of science materials in the school was very limited. In the interviews, both the key informant and the teachers emphasized that the science books were too difficult for the students to read, so they were in the teachers' closets or on the shelf in the teachers' classrooms, but were not used during the science instruction.

\section{Discussion}

There were four emerging themes that evolved as implicit findings during the study and they are discussed in the findings of the study. One of the most important themes that emerged from this study was that the six teachers emphasized that there are time barriers that exist for science instruction. The teachers taught science alternated with social studies during the last thirty minutes of the school day. This notion emerged from the interviews with the teachers as Teacher B stated, "One of the most difficult barriers to teaching science is that we do not have enough time to teach science." Teacher $\mathrm{C}$, a third grade teacher who participated in the study, also described the most difficult barriers to teaching science related to expository text was "not enough time" and that the "instructional materials are not on the academic level of the students." Reading instruction was first, and science came last of all the instructional priorities.

Secondly, there was limited availability and use of printed text in the observations. However, the difficult standardized science test passages rely on students' abilities to use, comprehend, and analyze expository test structures. As Wandersee (2001) has noted, during the past decade there has been more availability of teaching resources and instructional alternatives. Therefore, teachers have choices about where to locate expository text materials, and they have multiple strategies to select from to assist in teaching expository text structures that complement the sociocultural conversations and discussions that occur during science instruction. However, during the duration of this study, teachers used a limited number of expository test materials, and the majority of materials utilized in this study by the third, fourth, and fifth grade teachers included test practice student worksheets containing expository text.

Thirdly, the researcher's field and interview notes noted that although the teachers in this study used conversation and whole group discussion of science topics for science instruction, there was minimal use of informal or formal assessment of science instruction, and no assessment of science instruction using printed resources to assess the students' understanding.

Lastly, the teachers in this study used conversation in large group oral discussion as the primary instructional strategies, with minimal connection to printed resources including science textbooks. Students engaged in large group conversations and discussions without printed text resources during the science instruction in the last thirty minutes of a school day. 
Teachers in this study taught science at the end of the school day so science instruction was marginalized to the last 30 minutes of the school day usually two to three times per week. Federally funded and mandated reading instruction dominated the instructional minutes of the school day, so explicit instruction to build reading comprehension in science text structures was not integrated throughout the day. When students completed their assigned seat work, the researcher noted that there were minimal opportunities to connect with accessible informational books in classrooms, minimal access to science or informational resources and scarce amounts of time were spent using printed text materials matched with the instructional reading level of the students. Reading instruction was separate and first priority in the school day, and science instructional was minimized to minimal time at the end of the school day. Reading was first, and science was last on the list of priority for instruction.

Teachers' personal values as well as their attitudes toward reading instruction may have affected the reading strategy instruction the teachers used within their elementary classrooms. Demographic variables may have influenced the teachers' choice of the reading strategies they used to teach science using expository text; however, controlling for these complex situations was beyond the scope of this study.

Lack of time for science instruction, minimal connections with print resources or integration of reading strategies with printed text, lack or absence of assessment strategies, and limited availability of print resources for students emphasize that science instruction comes last even though reading mandates emphasize the importance of the use of reading strategies in science instruction.

\section{Conclusion}

Implicit findings from this study indicate that more research is needed in the area of reading comprehension instruction (NRP, 2000). If students are reading quality material, their knowledge of the world will increase, including their vocabulary, with such richer world knowledge empowering future comprehension of topically related texts (Anderson \& Pearson, 1984). Durkin (1979), Goldman and Rakestraw (2000), and Duke and Pearson (2002) emphasize that students who learn to use the organization and structure of informational texts are better able to understand and retain the information found in them.

There has been no previous time in history when the success of nations and people has been so dependent on their ability to learn. National concern continues to grow because our students are falling behind students in other countries on various measures of academic achievement, and in particular, on measures of reading comprehension (Lee, Grigg, \& Donahue, 2007; Snow, 2002).

A response to the reading crisis has been the attempt to ensure that every teacher is a teacher of reading, and not regarded the sole responsibility of the English and reading teachers. However, we are still awaiting this focus to show significant changes in the ways that content area teachers provide explicit strategy instruction above third grade in the elementary school. 
Current trends and national concerns place heavy demands on teachers so they can ensure that all students achieve high levels of literacy, and teachers often feel overwhelmed by the challenge. Often, the teachers experience uncertainty about how to teach specific reading comprehension strategies in an effort to foster the integration and evaluation of the informational texts above the third grade level.

Many children have not received sufficient instruction in the skills and strategies they need to understand expository text. Unfortunately, many students are unable to use appropriate reading strategies to enhance their learning in the science classroom because many teachers are at a loss as how to provide explicit teaching of reading strategies using expository text.

Educators agree that science students must meet the high standards for literacy success. The RAND report (Snow) commissioned by the U.S. Department of Education have identified that literacy proficiency is reached when the:

Reader can read a variety of materials with ease and interest, can read for varying purposes, and can read with comprehension even when the materials is neither easy to understand nor intrinsically interesting... [P]roficient readers...are capable of acquiring new knowledge and understanding new concepts, are capable of acquiring new knowledge and understanding new concepts, are capable of applying textual information appropriately, and are capable of being engaged in the reading process and reflecting on what is being read (p. xiii)

One of the IRA/NCTE standards state that students need to read a wide range of print and non-print texts to build an understanding of texts, of themselves, and of the cultures of the United States and the world through reading a variety of texts that include fiction and nonfiction, or expository texts.

Alignment of the elementary science curriculum with the current basal reading programs could offer additional insight to extend students' conversations and increase their background knowledge. Connecting conversation in science classrooms through inquiry-based learning to application of reading visual print and graphic resources can be further expanded to research how printed text carries visual information to help students use multimodal texts to convey information about science topics. Interaction with print resources with both visual and verbal modes might lead to improved reading comprehension in the $21^{\text {st }}$ century.

\section{References}

Alexander, P. A. (1997). A case for the motivational nature of exposition: Contrasting information finding with knowledge seeking. Paper presented at the American Educational Research Association, Chicago, IL.

Alexander, P., \& Jetton, T. (2000). Learning from text: A multidimensional and developmental perspective. In M. L. Kamil, P. B. Mosenthal, P. D. Pearson, \& R. Barr (Eds.). Handbook of Reading Research (Vol. 3, pp. 285-310). Mahwah, NJ: Erlbaum.

Anderman, E. M., \& Wolters, C. A. (2006). Goals, values, and affect: Influences on student 
motivation. In P. A. Alexander and P. H. Winne (Eds.), Handbook of educational psychology ( $2^{\text {nd }}$ ed., pp. 369-389). Nahwah, NJ: Erlbaum.

Anderson, R. C., \& Pearson, P.D. (1984). A schema-theoretic view of basic processes in reading comprehension. In P.D. Pearson, R. Barr, M.L. Kamil, \& P. Mosehthal (Eds.), Handbook of reading research (pp. 255-291). New York: Longman.

Beckers, G.G., Cheek, E.H., \& Ortlieb, E. (2009). Examining the treatment fidelity and social validity of a peer-mediated postsecondary reading intervention. Reports from the $59^{\text {th }}$ Annual National Reading Conference, Albuquerque, NM. Available at ftp://conflibs.nrconline.org/59th_Annual_Mtg/NRC_2009_Paper.pdf

Block, C.C., \& Rodgers, L. \& Johnson, R. (2004). Comprehension process instruction: Creating reading success in grades $K-3$ : New York: Guilford.

Cassidy, J., \& Ortlieb, E. (2013a). The evolution of what's hot in literacy. Journal of

Balanced Reading Instruction, 1(2), 12-17. Available at:

http://www.balancedreadinginstruction.com/uploads/1/8/9/6/18963113/ejbri_v1i2_cassidy ortlieb_evolution_of_whats_hot.pdf

Cassidy, J., \& Ortlieb, E. (2013b). What was hot (and not) in literacy: What we can learn.

Journal of Adolescent \& Adult Literacy, 57(1), 21-29. doi:10.1002/JAAL.215

Cassidy, J., \& Ortlieb, E. (2012). Looking at literacy in the $21^{\text {st }}$ century. The Clearing House, 85(4), 141-145.

Cassidy, J., \& Ortlieb, E. (2011). Literacy - The first decade of the new millennium. Reading Horizons, 51(2), 93-102.

Cassidy, J., Ortlieb, E., \& Shettel, J. (December 2010/January 2011). What's hot for 2011: Survey reveals a focus beyond the primary grades. Reading Today, 28(3), 1, 6-7.

Cassidy, J., Ortlieb, E., \& Shettel, J. (December 2010/January 2011). What's hot: The making of the list. Reading Today, 28(3), 8.

Collins, M., \& Cheek, E. H. (1999). Assessing \& guiding reading instruction. USA: McGraw-Hill Companies, Inc.

Cramer, N., Ortlieb, E.T., \& Cheek, E.H. (2008). Changing our students' perception about reading. Academic Exchange Quarterly, 12(1), 29-34.

Cramer, N., Ortlieb, E.T., \& Cheek, E.H. (2007, December). Multiple ways of knowing: A theoretical framework for drama and literacy in a contemporary curriculum. The Reading Matrix, 7(3), 35-42.

DeWalt, K. M., \& DeWalt, B. R. (2002). Participant observation: A guide for fieldworkers. Walnut Creek, CA: Alta-Mira Press.

Dimino, J. A. (2007). Bridging the gap between research and practice. Journal of Learning Disabilities, 40, 183-189.

Durkin, D. (1979). What classroom observations reveal about reading comprehension instruction. Reading Research Quarterly, 4, 481-533. 


\section{MInstitute Macrothink $_{\text {Int }}$}

Journal of Sociological Research

ISSN 1948-5468

2014, Vol. 5, No.1

Duke, N. K., \& Pearson, P. P. (2002). Effective practices for developing reading comprehension. In A.E. Farsup and S. J. Samuels (Eds.). What research has to say about reading instruction, $3^{\text {rd }}$ ed. (pp. 205-242). Newark, DE: International Reading Association.

Duke, N. K. (2000). 3.6 minutes per day: The scarcity of informational text in the first grade. Reading Research Quarterly, 35, 202-224.

Duke, N. K. (2006). The case for informational text. The Reading Teacher, 60(2), 177-181.

Durkin, D. (1978-79). What classroom observations reveal about reading comprehension instruction. Reading Research Quarterly, 4, 481-533.

Gaffney, J. S. \& Anderson, R. C. (1991). Two tiered-scaffolding: Congruent processes ofteaching and learning. In E. H. Hiebert (Ed.) Literacy for a diverse society (pp. 184-198). New York: Teachers College Press.

Gaskins, I.W. (2005). Success with struggling readers. The benchmark school approach. New York: Guilford.

Gaskins, I.W. (2008). Ten tenets of motivation for teaching struggling readers - and the rest of the class. In R. Fink \& S. J. Samuels (Eds.), Inspiring reading success: Interest and motivation in an age of high-stakes testing (pp. 98-116). Newark, DE: International Reading Association.

Goldman, S. R. \& Rakestraw, J. A. (2000). Structural aspects of constructing meaning from text. In M. L. Kamil, P. B. Mosenthal \& R. Barr (Eds.). (2000). Handbook of reading research: Volume III (pp. 53-74). Mahwah, NJ: Erlbaum.

Hilden, K. R., \& Pressley, M. (2007). Self-regulation through instructional strategies instruction. Reading and Writing Quarterly, 23, 51-75.

International Reading Association and the National Council of Teachers of English (1996). Standards for the English Language Arts.

Kamil , M., Mosenthal, P., Pearson, D., \& Barr, R.(2000). Handbook of Reading Research, Vol.III. Routledge.

Laster, K.P., Ortlieb, E.T., \& Cheek, Jr., E.H. (2009). Beyond skill instruction: Promoting literacy acquisition in kindergarten. International Journal of Education, 1(1), E5.

Lee, J., Grigg, W., \& Donahue, P. (2007). The Nation's Report Card: Reading 2007 (NCES 2007-496). Washington, DC: U.S. Department of Education, Institute of Education Sciences, National Center for Education Statistics.

Lipson, M. Y. (2007). Teaching reading beyond the primary grades. New York: Scholastic.

McKeown, M. G., Beck, I. L., Blake, R. G. (2009). Rethinking reading comprehension: A comparison of instruction for strategies and content approaches. Reading Research Quarterly, 44(3), 218-253.

Moss, B. (2005). Making a case and a place for effective content area literacy instruction in the elementary grades. The Reading Teacher, 59(1), 46-55.

National Center for Education Statistics (NCES) (2006). Digest of education statistics 2005. NCES 2006-030. Washington, DC.

National Institute of Child Health and Human Development. (2000). Report of the National Reading Panel. Teaching children to read: An evidence-based assessment of the scientific research literature on reading and its implications for reading instruction (NIH Publication 


\section{I Macrothink}

No. 00-4769). Washington, DC: US Government Printing Office.

National Research Council (1996). National Science Education Standards. Washington, DC: National Academy Press.

No Child Left Behind Act of 2001, Pub. L. No.107-110, 115 Stat. 1425 (2002).

Ortlieb, E. (2014). Literacy Research, Practice and Evaluation: Vol. 4. Theoretical models of learning and literacy development. Bingley, UK: Emerald Group.

Ortlieb, E. (2013). Learning to spell proficiently: Best practices from a Spelling Bee Champion. In N. Zunker (Ed.), Preparing effective educators for tomorrow's schools (pp. 41-56). Corpus Christi, TX: Texas A\&M University Corpus Christi. Available at: http://ceder.tamucc.edu/files/CEDER_2013.pdf\#page=51

Ortlieb, E. T. (2008). Teaching reading in rural and urban elementary schools. Germany: VDM Verlag Dr. Mueller e.K.

Ortlieb, E.T., Cramer, N., \& Cheek, E.H. (2007). The art of reading: Dramatizing literacy. Reading Improvement, 44(3), 169-176.

Ortlieb, E.T., \& Cheek, E.H. (2008). How geographic location plays a role within instruction: Venturing into both rural and urban elementary schools. Educational Research Quarterly, $32(1), 48-64$.

Ortlieb, E., Verlaan, W., \& Cheek, Jr., E.H. (2013). Fostering proactive reading instruction within the content areas. In E. Ortlieb \& E.H. Cheek, Jr. (Eds.), Literacy Research, Practice, and Evaluation: Vol. 3. School-based interventions for struggling readers, K-8 (pp. 21-40). Bingley, UK: Emerald Group.

Ortlieb, E., Cheek, Jr., E.H., \& Verlaan, W. (2013). Vocabulary/comprehension-based models of reading clinics. In E. Ortlieb \& E.H. Cheek, Jr. (Eds.), Literacy Research, Practice, and Evaluation: Vol. 2. Advanced literacy practices: From the clinic to the classroom (pp. 117-136). Bingley, UK: Emerald Group.

Ortlieb, E.T., \& Cheek, Jr., E.H. (Eds.) (2013). Literacy Research, Practice, and Evaluation: Vol. 3. School-based interventions for struggling readers, K-8. Bingley, UK: Emerald Group.

Ortlieb, E.T., \& Cheek, Jr., E.H. (Eds.) (2013). Literacy Research, Practice, and Evaluation: Vol. 2. Advanced literacy practices: From the clinic to the classroom. Bingley, UK: Emerald Group.

Ortlieb, E.T., \& Cheek, Jr., E.H. (Eds.) (2012). Literacy Research, Practice, and Evaluation: Vol. 1. Using informative assessments for effective literacy instruction. Bingley, UK: Emerald Group. 


\section{Mll Macrothink}

Journal of Sociological Research

ISSN 1948-5468

2014, Vol. 5, No.1

Ortlieb, E.T., \& Doepker, G.M. (2009). Modernizing the reading clinic through research and exploration. Conference proceedings from The SOTL Commons: A Conference for the Scholarship of Teaching and Learning, Available: http://academics.georgiasouthern.edu/ijsotl/conference/proceedings/2009/papers.htm

Ortlieb, E., \& Marinak, B. A. (2013). Surveying digital literacy use and motivation in elementary school students. Basic Research Journal of Education Research and Review, 2(5), 81-88.

Paris, S. D., Lipson, M. Y., \& Wixson, K. K. (1983). Becoming a strategic reader. Contemporary Educational Psychology, 8, 293-316.

Perie, M., Grigg, W. S., \& Donahue (2005). The nation's report card: Reading 2005. NCES Publication no. 2006-451. Washington,, D.C.: National Center for Education Statistics.

Pressley, M., El-Dinary, P. B., \& Brown, R. (1992). Skilled and not-so-skilled reading: Good information processing and not-so-good information processing. In M. Pressley, K.R. Harris \& J.T. Guthrie (Eds.), Promoting academic competence and literacy in School (pp. 91-127). New York: Guilford.

Pressley, M., \& Harris, K. (2006). Cognitive strategies instruction: From basic research to classroom instruction. In P. Alexander \& P. Winne (Eds.), Handbook of educational psychology, $2^{\text {nd }}$ ed. (pp. 265-286). Mahwah, NJ: Erlbaum.

Pressley, M. (2002a). Comprehension strategies instruction: A turn-of-the-century status report. In C. C. Block \& M. Pressley (Eds.), Comprehension instruction: Research-based best practices (pp. 11-27). New York: Guilford.

Pressley, M. (2002b). Reading instruction that works: The case for balanced teaching. New York: Guilford.

Santa, C. M., Havens, L. T., \& Valdes, B. J. (2004). Project CRISS: Creating independence through student owned strategies. Dubuque, IA: Kendall Hunt Publishers.

Saul, E. W. (2004). Crossing borders in literacy and science instruction: Perspectives on theory and practice. Newark, DE: International Reading Association, Inc.

Smolkin, L. B. \& Donovan, C. A. (2003). Supporting comprehension acquisition for emerging and struggling readers: The interactive information read-aloud. Exceptionality, 11, 25-38.

Snow, C. E., Burns, M. S., \& Griffin, P. (1998). Preventing reading difficulties in young children. Washington, DC: National Research Council.

Snow, C. (2002). Reading for understanding. Santa Monica, CA: RAND.

Spradley, J. P. (1980). Participant observation. USA: Wadsworth.

Walpople. S., Justice, L.M., \& Invernizzi, M. A. (2004). Closing the gap between research and practice: Case study of school-wide literacy reform. Reading and Writing Quarterly, 20, 261-283.

Wandersee, J.H. (2001). High school biology instruction. Targeting deeper understanding for biological literacy. In J. Brophy (Ed.) Subject specific instructional methods and activities (pp. 187-214). Amsterdam: JAI.

Yore, L. D. (2004). Why do future scientists need to study the language arts? In E.W. Saul 
(Ed.), Crossing borders in literacy and science instruction: perspectives on theory and practice (pp. 71-94). Newark, DE: International Reading Association. 